\title{
An improved method for the measurement of red cell survival using non-radioactive chromium
}

\author{
H. C. DRYSDALE 1 , P. M. EMERSON², AND A. HOLMES 3 \\ From ${ }^{1}$ the Department of Pathology, Princess Margaret Hospital, Swindon, ${ }^{2}$ the Department of \\ Haematology, Radcliffe Infirmary, Oxford, and ${ }^{3}$ the Environmental and Medical Sciences Division, \\ United Kingdom Atomic Energy Authority, Atomic Energy Research Establishment, Harwell, UK
}

SUMMARY An improved technique for the measurement of red cell survival is described in which non-radioactive ${ }^{50} \mathrm{Cr}$ is used in patients for whom radioactive labels are not advisable. The ${ }^{50} \mathrm{Cr}$ was measured by neutron activation analysis using a high resolution germanium (lithium) diode gammaray spectrometer. In adult controls, the values obtained were in the range accepted as normal for the ${ }^{51} \mathrm{Cr}$ method, and double labelling experiments showed close agreement. The application of this technique to the measurement of red cell survival in pregnant women suspected of having haemolytic anaemia is described.

The generally recognised technique for the measurement of red cell survival time is by the infusion of cells labelled with ${ }^{51} \mathrm{Cr}$ and the measurement of this nuclide in serial blood samples taken subsequently (Ebaugh et al., 1953). However, the use of radioactive tracers is not advisable in pregnant women and children. In 1968, Donaldson et al. described an alternative method, in which cells labelled with inactive chromium enriched in ${ }^{50} \mathrm{Cr}$ (normal abundance $4.3 \%$ ) were reinfused, and the chromium content of subsequent blood samples was determined by neutron activation analysis. The induced ${ }^{51} \mathrm{Cr}$ was measured using sodium iodide detectors. This method required the labelling of $200 \mathrm{ml}$ of blood and was later modified by Uchiyama et al. (1975), who used smaller quantities and more sensitive instrumentation. Glomski et al. (1976) described its use in children with various haemolytic anaemias using volumes of blood that are appropriate for the paediatric age group.

We describe a further modification of the technique, in which the precision is increased by expressing the results as the ${ }^{50} \mathrm{Cr} /{ }^{59} \mathrm{Fe}$ ratio, the iron being the natural inherent red cell iron activated by the neutron flux. Its application to the measurement of erythrocyte survival in normal and haemolysing pregnant women is described, and a fingerprick technique for the collection of blood samples from children, with recommendations on the minimal amounts of blood needed for labelling, is also given.

Received for publication 13 December 1978

\section{Patients and methods}

PATIENTS

Informed consent was obtained from all 10 subjects used in the study. The control group consisted of two men, two premenopausal women, and two women in the last trimester of pregnancy. The patient group consisted of three women in the last trimester of pregnancy who were suffering from congenital haemolytic anaemia and a 67-year-old man with hereditary spherocytosis.

BLOOD LABELLING AND SAMPLING

The stable chromium was prepared by electromagnetic separation at Harwell. The chromium, in the chemical form $\mathrm{Cr}_{2} \mathrm{O}_{3}$, was converted to sodium chromate and dissolved in pyrogen-free water before use. The isotopic composition was: ${ }^{50} \mathrm{Cr} 96.80 \%,{ }^{52} \mathrm{Cr} 2.98 \%,{ }^{53} \mathrm{Cr} 0.18 \%,{ }^{54} \mathrm{Cr} 0.04 \%$.

Venous blood $(50 \mathrm{ml})$ was anticoagulated with ACD, and the packed red cells were incubated with stable ${ }^{50} \mathrm{Cr}$ as sodium chromate $(500 \mu \mathrm{g})$ to give $10 \mu \mathrm{g} / \mathrm{ml}$, a concentration not thought to damage red cells, at room temperature for 30 minutes, washed twice with normal saline, and resuspended with saline before re-introduction into the patient.

Blood samples were taken into lithium heparin tubes before injection as a control, at 45 minutes post-injection, and thereafter at regular intervals for 28 days. There was no chromium contamination from the standard steel needles used for venepuncture. At Harwell approximately $0.2 \mathrm{ml}$ of 
blood from each specimen was transferred into clean silica capillary tubes $(6 \mathrm{~cm} \times 3 \mathrm{~mm})$ and dried initially at $67^{\circ} \mathrm{C}$ to avoid losses, and finally at $110^{\circ} \mathrm{C}$. Both ends of the tube were then sealed using 'heat shrink' PTFE tubing, which will withstand neutron activation. For the 'fingerprick' technique, samples of capillary blood were collected directly into the silica capillary tubes, dried as above, and then dispatched to Harwell for activation.

\section{NEUTRON ACTIVATION AND RADIOACTIVE MEASUREMENTS}

The irradiations were carried out at a thermal neutron flux of $6 \times 10^{12} \mathrm{n} / \mathrm{cm}^{2} / \mathrm{s}$ in either the DIDO or PLUTO Harwell reactors for 10 days, and the short-lived activation products were allowed to decay for two weeks before counting was started.

Induced radioactivity of the samples was measured on a germanium (lithium) detector gamma-ray spectrometer controlled by a data acquisition system (Salmon and Creevy, 1971). Figure 1 shows a typical gamma-ray spectrum of a sample of irradiated blood labelled with ${ }^{50} \mathrm{Cr}$. The chromium and iron contents were determined by means of the GASP programme (Salmon, 1965) using a linear regression analysis in which the pulse-height distribution was compared with those from individual radiochemically pure samples of each component nuclide. This technique is inherently more accurate than the more commonly used peak area measurements.

In the double labelling experiments, determinations of the ${ }^{51} \mathrm{Cr}$ from the radioactive label were made using the normal hospital procedure (Dacie and Lewis, 1975), and the total gamma disintegrations were counted in a well-type $\mathrm{NaI}$ crystal. The ${ }^{51} \mathrm{Cr}$ was allowed to decay before activation in the reactor and measurement on the germanium (lithium) system.

The results were expressed conventionally as $\mathrm{T}_{\frac{1}{2}}{ }^{50} \mathrm{Cr}$ (the time taken for disappearance of half the chromium from the blood) rather than the mean cell life, as recommended by the International Committee for Standardization in Haematology (ICSH) (1971), in order to compare these results with those of previous authors. All results are the mean of five determinations unless otherwise stated.

\section{Results}

The overall results on six control subjects and four patients with haemolytic anaemia are shown in Table 1. The half-times obtained by measuring the absolute chromium content per unit of blood, as in the conventional ${ }^{51} \mathrm{Cr}$ method, are compared with those calculated from the chromium content relative to iron where the iron acts as an internal standard. There is close agreement between the two methods except in one control patient (No. 1) who was the first subject investigated before the technique was perfected.

The results of a double labelling study using ${ }^{51} \mathrm{Cr}$ and ${ }^{50} \mathrm{Cr}$ on an adult male suffering from hereditary spherocytosis are shown in Figure 2. There is close agreement between the two methods, the $T_{ \pm}$for the three plots shown being 14.3 \pm 0.9 , $13.7 \pm 0.8$, and $14.0 \pm 0.6$ days, respectively.

Figures $3 \mathrm{a}$ and $3 \mathrm{~b}$ show the results obtained during the third trimester of a normal pregnancy together with the curve on a pregnant patient suffering from pyruvate kinase deficiency. The latter demonstrates well the presence of a double population of cells in this condition (Nathan et al., 1968).

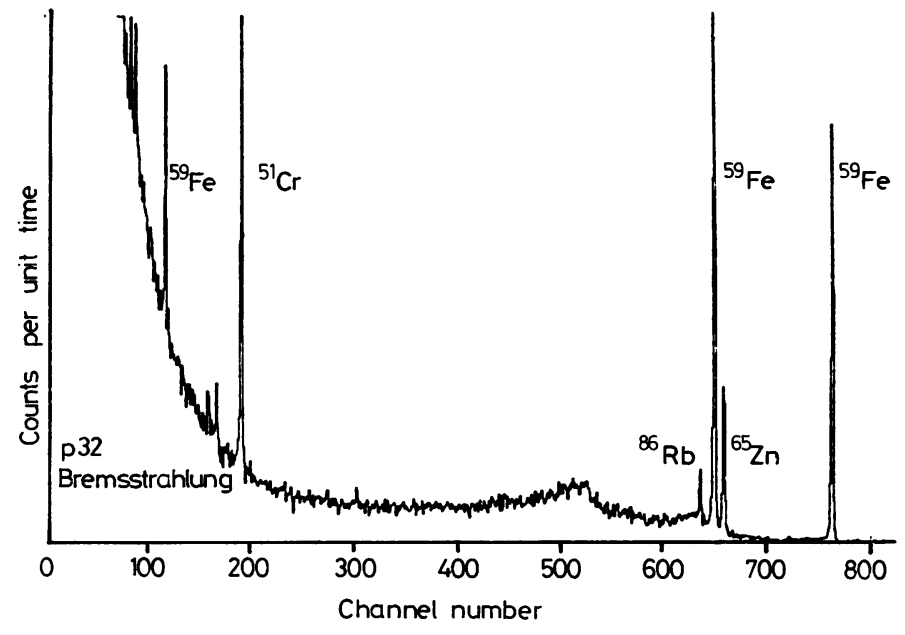

Fig. 1 Gamma-ray spectrum of neutron-activated peripheral blood labelled with stable ${ }^{50} \mathrm{Cr}$. 
Table 1 Half-times in controls and haemolysing patients comparing absolute chromium-50 content with chromium-50 content relative to iron-59

\begin{tabular}{|c|c|c|c|c|}
\hline No. & Subject & Condition & $\begin{array}{l}\text { Half-time by absolute }{ }^{50} \mathrm{Cr} \\
\text { content } \pm S D\end{array}$ & $\begin{array}{l}\text { Half-time by }{ }^{50} \mathrm{Cr} \text { content } \\
\text { relative to }{ }^{59} \mathrm{Fe} \pm S D\end{array}$ \\
\hline $\begin{array}{r}1 \\
2 \\
3 \\
4 \\
5 \\
6 \\
7 \\
8 \\
9 \\
10\end{array}$ & $\begin{array}{l}\text { Normal male } \\
\text { Normal male } \\
\text { Normal male } \\
\text { Normal male } \\
\text { Pregnant } \\
\text { Pregnant } \\
\text { Pregnant } \\
\text { Pregnant } \\
\text { Pregnant } \\
\text { Male }\end{array}$ & $\begin{array}{l}\text { Control } \\
\text { Control } \\
\text { Control } \\
\text { Control } \\
\text { Control } \\
\text { Control } \\
\text { Hereditary spherocytosis } \\
\text { Hereditary spherocytosis } \\
\text { Pyruvate kinase deficiency } \\
\text { Hereditary spherocytosis }\end{array}$ & $\begin{array}{l}17 \cdot 5 \pm 3 \cdot 4 \\
25 \cdot 1 \pm 3 \cdot 8 \\
21 \cdot 8 \pm 1 \cdot 7 \\
30 \cdot 7 \pm 3 \cdot 8 \\
37 \cdot 1 \pm 7 \cdot 4 \\
38 \cdot 8 \pm 2 \cdot 5 \\
25 \cdot 7 \pm 1 \cdot 9 \\
17 \cdot 2 \pm 2 \cdot 2 \\
-\end{array}$ & $\begin{array}{l}23.7 \pm 3.2 \\
28 \cdot 1 \pm 3.7 \\
21.6 \pm 1.4 \\
30.3 \pm 0.9 \\
35.3 \pm 4.9 \\
39.0 \pm 1.5 \\
20.3 \pm 0.7 \\
17.2 \pm 0.7 \\
15.0 \pm 0.7 \\
13.7 \pm 0.8\end{array}$ \\
\hline
\end{tabular}

*Duplicate determinations only
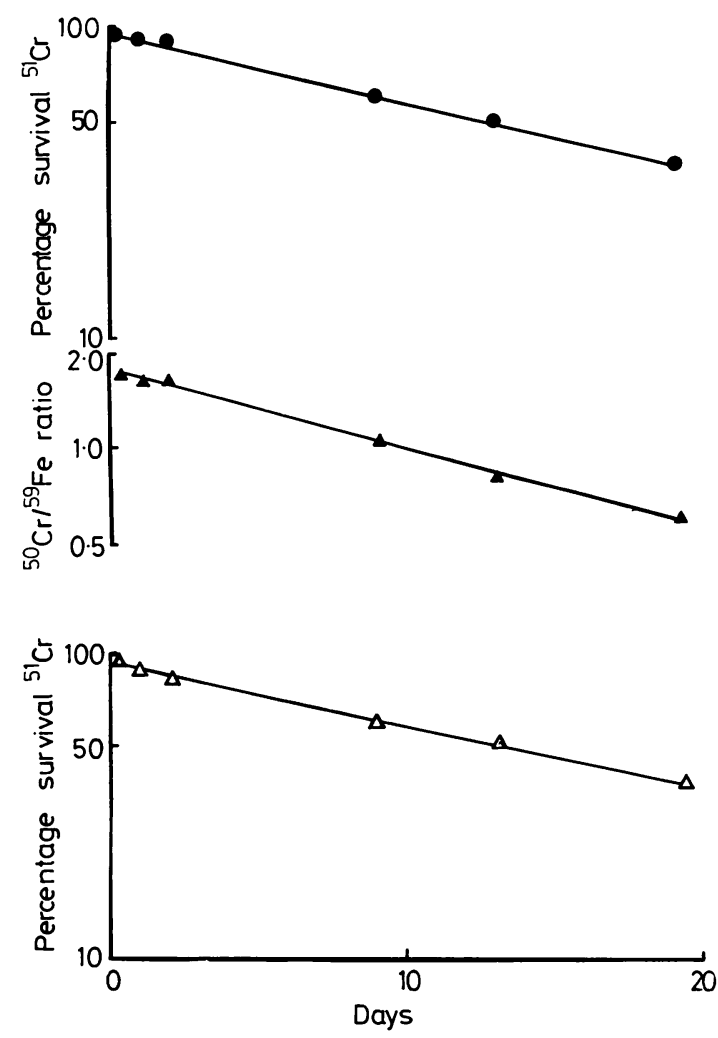

Fig. 2 Double labelling experiment using ${ }^{51} \mathrm{Cr}$ and ${ }^{50} \mathrm{Cr}$. Results obtained at Harwell $(\longrightarrow$ and $\Delta) T_{\frac{1}{2}}{ }^{51} \mathrm{Cr}=$ $14 \cdot 4 \pm 0 \cdot 9, \mathrm{~T}_{\frac{1}{2}}{ }^{50} \mathrm{Cr} 13 \cdot 7 \pm 0 \cdot 8$ days. Results obtained at local hospital $(\triangle) T_{\frac{1}{2}}{ }^{51} \mathrm{Cr}=14 \cdot 0 \pm 0 \cdot 6$ days.

The chromium/iron ratio is a satisfactory way of expressing the results and possibly superior, as shown by the smaller standard deviations. The $\mathrm{T}_{\frac{1}{2}}{ }^{50} \mathrm{Cr}$ for the haemolysing group are all reduced, as would be expected, and of interest is the relatively long half-time observed in the two normal pregnant women. Further studies are needed to assess the normal life span at various stages of pregnancy by this method.

\section{Discussion}

Radioactive chromium was initially introduced as a measure of the red cell mass but was subsequently swiftly adopted for red cell survival studies (Ebaugh et al., 1953; Necheles et al., 1953). Comparison of the corrected survival curves with the simultaneous use of labelled di-isopropyl phosphofluoridate showed good concordance. Nevertheless the use of even small doses of radioactivity is contraindicated in infancy and pregnancy, and so the introduction of the use of stable chromium with neutron irradiation in vitro promised an alternative approach to this problem. Unfortunately, the method and techniques of Donaldson et al. (1968) and Johnson et al. (1969) necessitated the use of $100-200 \mathrm{ml}$ of blood, but subsequent refinements have enabled this amount to be substantially reduced. The observations reported here parallel those of Uchiyama et al. (1975), who labelled $50 \mathrm{ml}$ of blood with a concentration of chromium at or below the level of $10 \mu \mathrm{g} / \mathrm{ml}$ of red cells, a concentration thought not to affect the subsequent red cell life span. This paper demonstrates that the chromium/iron ratio, by providing an internal standard, has improved the replicate precision and gives good correlation with the radioactive chromium results. This method also obviates the need for weighing samples, and for repeated PCV estimations during the survival.

Toxicological data indicate that only a negligible quantity of administered chromium will cross the placental barrier (Visek et al., 1953). Furthermore, the chromium in the concentrations involved appears to be non-toxic (Anwar et al., 1961). The method, therefore, seems to be ideally suited for the 

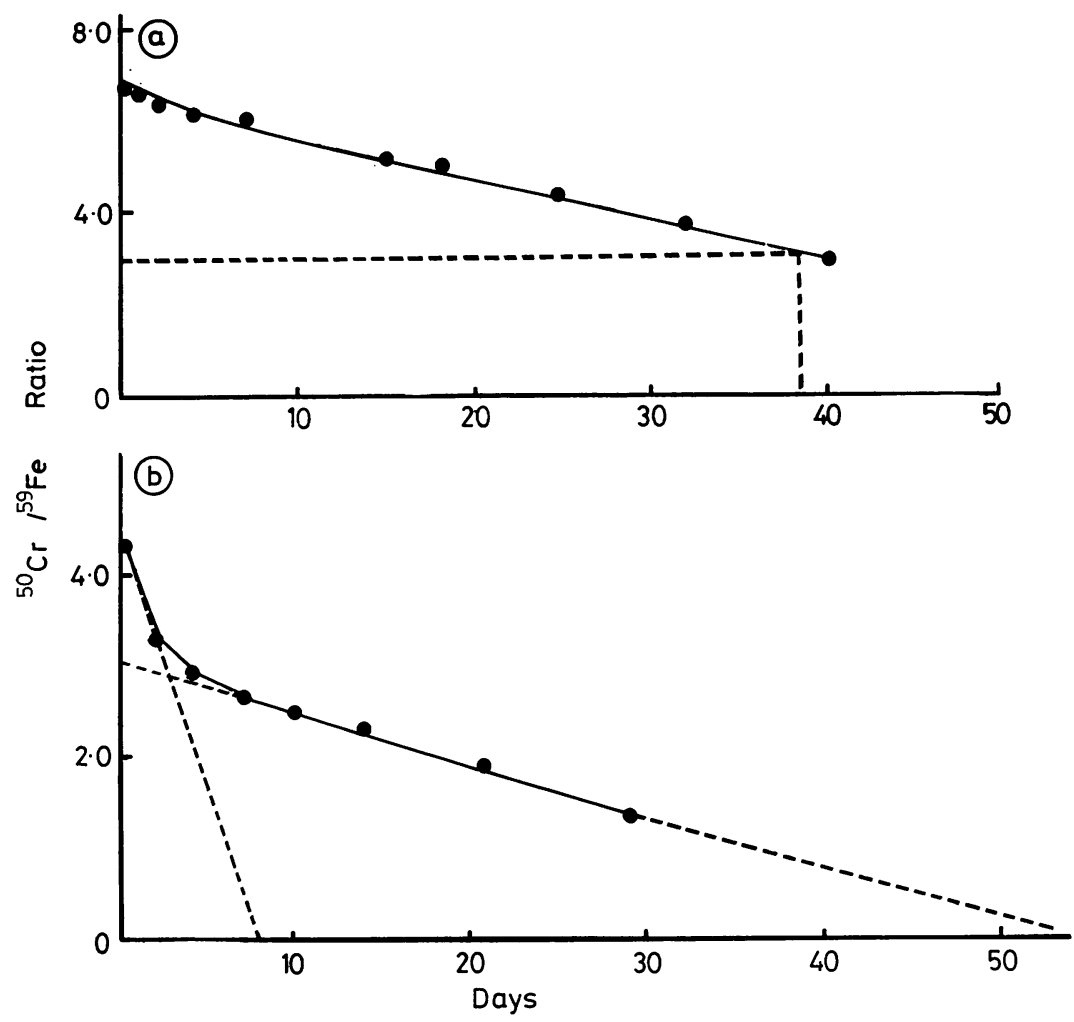

Fig. 3a Red cell survival in normal pregnancy. Each point represents the mean of five determinations. Standard errors for each point are too small to be shown graphically (mean $0.07) T_{\frac{1}{2}}^{50} \mathrm{Cr}=39.0$ \pm 1.5 days.

Fig. 3b Red cell survival in pregnancy complicated by congenital pyruvate kinase deficiency. The curve demonstrates a double population of cells. Population $160 \%$ $(M C L=56$ days $)$. Population II $40 \%$ (MCL $3 \cdot 5$ days). $\mathrm{T}_{1}{ }^{50} \mathrm{Cr}=25 \cdot 1$ \pm 1.2 and $0.7 \pm 0.2$ days respectively (double exponential fit). investigation of red cell survivals. Further, there is no reason why it cannot also be applied to red cell mass determination, and, as stated earlier, the method is ideally suited for investigating the complex haematological changes that occur during pregnancy.

Analysis of samples can be undertaken on volumes as low as $0.2 \mathrm{ml}$, which makes sequential sampling by the fingerprick technique, especially in infancy, much easier. Table 2 shows recommended amounts

Table 2 Typical blood volumes of children during growth calculated from mean body weights and volumes of chromium-50-labelled blood needed for infusion

\begin{tabular}{rlll}
\hline & $\begin{array}{l}\text { Mean weight } \\
(\mathrm{kg})\end{array}$ & $\begin{array}{l}\text { Blood volume } \\
(\mathrm{ml})\end{array}$ & $\begin{array}{l}\text { Volume of } \\
\text { labelled blood for } \\
\text { infusion }(\mathrm{ml})\end{array}$ \\
\hline Premature & - & $100-150$ & $1-1 \cdot 5$ \\
Birth & $3 \cdot 2$ & 300 & $2 \cdot 7$ \\
1 & $10 \cdot 1$ & 720 & 5 \\
2 & $12 \cdot 6$ & 900 & 8 \\
4 & $16 \cdot 5$ & 1200 & 11 \\
6 & $21 \cdot 9$ & 1560 & 14 \\
8 & $27 \cdot 3$ & 1950 & 18 \\
10 & $32 \cdot 6$ & 2330 & 21 \\
12 & $38 \cdot 3$ & 2730 & 25 \\
14 & $48 \cdot 8$ & 3490 & 32 \\
16 & $58 \cdot 8$ & 4200 & 38 \\
18 & $63 \cdot 1$ & 4510 & 41 \\
\hline
\end{tabular}

of blood needed for labelling throughout childhood and adolescence which are slightly smaller than those used by Glomski et al. (1976). Because of their small volume all the samples can be irradiated together, thus avoiding inaccuracies due to variations in neutron flux with time. The main drawbacks of the method remain the delay in obtaining the result and the cost. Two to three weeks must elapse after irradiation to allow for the decay of the shorter lived induced nuclides, and so overall about two months must elapse between the beginning of the estimation and the final result. The current cost of the irradiation and analysis at Harwell is about $£ 125$ per patient but this should be balanced against the saving in doctors' and technicians' time, and we feel strongly that any means by which exposure to irradiation can be limited is a distinct advantage.

We thank Mr J. Darley for technical help, and the Oxford Regional Health Authority for financing this project.

\section{References}

Anwar, R. A., Langham, R. F., Hoppert, C. A., Alfred- 
son, B. V., and Byerrum, R. U. (1961). Chronic toxicity studies III. Chronic toxicity of cadmium and chromium in dogs. Archives of Environmental Health, 3, 456-460.

Dacie, J. V., and Lewis, S. M. (1975). Practical Haematology, 5th edition, p. 457. Churchill Livingstone, Edinburgh.

Donaldson, G. W. K., Johnson, P. F., Tothill, P., and Richmond, J. (1968). Red cell survival in man measured by ${ }^{50} \mathrm{Cr}$ and activation analysis. British Medical Journal, 2, 585-587.

Ebaugh, F. G., Jr., Emerson, C. P., and Ross, J. F. (1953). The use of radioactive chromium 51 as an erythrocyte tagging agent for the determination of red cell survival in vivo. Journal of Clinical Investigation, 32, 1260-1276.

Glomski, C. A., Pillay, K. K. S., and Macdougall, L. G. (1976). Erythrocyte survival in children as studied by labeling with stable ${ }^{50} \mathrm{Cr}$. American Journal of Diseases of Children 130, 1228-1230.

International Committee for Standardization in Haematology (ICSH) (1971). Recommended methods for radioisotope red-cell survival studies. British Journal of Haematology, 21, 241-250.

Johnson, P. F., Tothill, P., and Donaldson, G. W. K. (1969). Stable chromium as a tracer for red cells, with assay by neutron activation analysis. International Journal of Applied Radiation and Isotopes, 20, 103-108.

Nathan, D. G., Oski, F. A., Miller, D. R., and Gardner, F. H. (1968). Life-span and organ sequestration of the red cells in pyruvate kinase deficiency. New England Journal of Medicine, 278, 73-81.

Necheles, T. F., Weinstein, I. M., and LeRoy, G. V. (1953). Radioactive sodium chromate for the study of survival of red blood cells. I. The effect of radioactive sodium chromate on red cells. Journal of Laboratory and Clinical Medicine, 42, 358-367.

Salmon, L. (1965). A general computer program for the analysis of gamma-ray spectra. In Radiochemical Methods of Analysis, p. 125. International Atomic Energy Agency, Vienna.

Salmon, L., and Creevy, M. G. (1971). An on-line computer system for instrumental activation analysis of air, water and soil. In Nuclear Techniques in Environmental Pollution, p. 17. International Atomic Energy Agency, Vienna.

Uchiyama, G., Akiba, H., and Kakehi, H. (1975). Determination of red cell survival by activation analysis. International Journal of Nuclear Medicine and Biology, 2, 37-40.

Visek, W. J., Whitney, I. B., Kuhn, U. S. G., III, and Comar, C. L. (1953). Metabolism of $\mathrm{Cr}^{51}$ by animals as influenced by chemical state. Proceedings of the Society for Experimental Biology and Medicine, 84, 610-615.

Requests for reprints to: Dr Pauline M. Emerson, Department of Haematology, Gibson Laboratories, Radcliffe Infirmary, Oxford, UK. 